
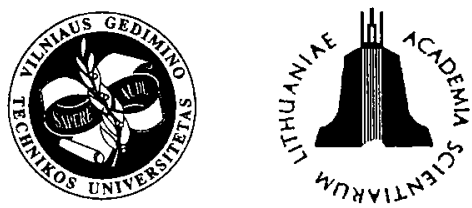

JOURNAL OF CIVIL ENGINEERING AND MANAGEMENT

http:/www.vtu.It/english/editions

2002, Vol VIII, No 4, 231-239

\title{
AN OVERVIEW OF THE PROBLEMS RELATED TO RESEARCH IN CONSTRUCTION ENGINEERING, MANAGEMENT AND ECONOMICS IN POLAND
}

\author{
Oleg Kapliński ${ }^{1}$, Edmundas K. Zavadskas ${ }^{2}$ \\ ${ }^{1}$ Poznan University of Technology, Division of Construction Engineering and Management, \\ 60-965 Poznan, Piotrowo 5, Poland. E-mail: Kapleg@put.poznan.pl \\ 2 Vilnius Gediminas Technical University, Saulètekio al. 11, LT-2040 Vilnius, Lithuania. \\ E-mail:Edmundas.Zavadskas@vtu.lt.
}

Received 29 Jun 2002; accepted 08 Oct 2002

\begin{abstract}
Problems related to research on the organization, management, economics and technology in the construction industry in Poland are discussed and evaluated in this paper. Scientific and, more specifically, academic circles are characterised and alarming phenomena that accompany practicing the issues of organization and management in construction engineering are discussed: an increase of the number of employees with economic education, phenomena related to finance, staff feminization and fluctuations among other things. Trends observed in research works and changes in the subject matter of interest to participants at scientific conferences are pointed out. Publication activity, dissertations and international cooperation are discussed. Non-serial publications of the last three years are listed. The analysis is based on a questionnaire circulated by the Construction Management Section of the Civil Engineering Committee of the Polish Academy of Science, the members of which are the authors of this article. The questionnaire covered a period of ten years. Furthermore, proceedings from conferences organized domestically under the patronage of the said Section as well as the effect of a trilateral international cooperation between Lithuania, Germany and Poland have been used.
\end{abstract}

Keywords: construction management, research, publications, dissertations, Poland.

\section{Introduction}

It has been observed that the problem of organization and management both in practice and in research in Poland has in the last decade been undergoing a specific renaissance. However, the phenomenon is not accompanied by participation, specifically of academic circles, in scientific conferences organized under the patronage of the Civil Engineering Committee of the Polish Academy of Science, as evidenced in the so-called "Krynica conferences", annually held in Krynica. This particular paradox is the background of the paper.

The fact that nationwide BUDIN seminars (organized by the Institute of Building Engineering of the Wrocław University of Technology, [1]) and the Risk Management conferences, organized by the University of Technology and Agriculture, Bydgoszcz, [2]) are present in the "renaissance stream" is only more optimistic. Worth noting is also the meeting before last of single-aspect teams representing construction technology, organization and economics, held in Puławy in 2001 [3] and conferring on four problem blocks:

(a) investment process in construction,

(b) management in a construction company,

(c) construction materials technology,

(d) construction process technology.
The papers tended observably toward the issues of investment process and management of a construction company, which were tackled in nearly three-fourths of the total number of papers.

This indicates that research in this circle tends to follow changes resulting from a market economy in the making. The question of using the research findings and the outcome of this kind of meetings may be approached with optimism.

The participants in the last conference, held in Olsztyn and Lańsk [4], are no longer as delighted in the phenomenon as they used to be. The problems of company management and investment process organization have become familiar and common. On the other hand, the profile of research has changed perceptibly: many papers showed research findings based on questionnaire circulation methods.

The number of researchers interested in the problem of construction engineering, organization and management is extremely large and they deal with a wide spectrum of problems: from legal questions in the construction industry to mechanization. It is represented primarily by academic centres. The fact is explained by the process of education in fields related to the subject: in civil engineering and related studies. These circles are 
represented in the Polish Academy of Science by the Construction Organization and Management Section of the Civil Engineering Committee.

To determine the condition and output of the research circles, a questionnaire was circulated by the members of the Section in 2000. Indirectly, the questionnaire reached 36 independent researchers (including associate professors and retired researchers) and 96 PhD's. The questionnaire covered the last decade and problems such as academic degrees and titles conferred and, first of all, publications; professional activity; international cooperation; didactic activity reaching beyond standards; phenomena and tendencies in scientific and didactic activities, in cooperation with industry and administration. A similar questionnaire is going to be circulated in Lithuania in 2002. Shown below are comments on part of the answers to the questionnaire; they largely characterise the researchers' environment and the status of research on the issue of construction organization and management in Poland. Included in the comments below are also observations made during four "TOB" (Construction Engineering and Management) conferences organized in Międzyzdroje [5], Gliwice-Kokotek [6], Puławy [3], Olsztyn - Łańsk [4] and a session debate about the same questions, held in Krynica [7-9].

\section{Alarming phenomena, accompanying the practic- ing of the issues of construction organization and management}

Several phenomena of a more general nature are observed among the researchers who responded to the questionnaire. One of them is a change in the structure of researchers in technical universities: the number of employees with economic education has increased dramatically, the highest percentage of economists, namely two-thirds of the staff working in the Department of Building Organization, Management and Engineering of the Academy of Technology of Agriculture, Bydgoszcz.

Other phenomena were observed in the area of finance, staff fluctuation and feminization. The financial issue was indicated by the respondents as the most buming one. Shortage of finance leads to problems in carrying out research works and affects the level of education. Our circles have adapted to the so-called Ministry of Education's algorithm which accounts for an increased recruitment of students and critically increased teaching load of our colleagues, as higher numbers of candidates for studies are observed specifically in our fields of study. The respondents tend to emphasize "rather (shockingly) low salaries of scientific/didactic employees of all levels".

Furthermore, the respondents have indicated the very limited possibilities of research cooperation with building contractors: the problem is that data on construction companies are hard to collect.

Some centres have accentuated a gradually intensifying process of feminization of the profession in our special- ist fields. Additionally, the above statement may be supported by the growing number of female students of doctoral studies.

Moreover, increased staff fluctuations have been observed, compared with the previous decades. This mobility of young people results from different working conditions, there also appears to be a clear (negative) influence of their salaries. The effect is that some centres are not capable of forecasting who might start and who might conclude writing their doctoral dissertations.

It seems to me that another important phenomenon should be mentioned here. It may be labelled as "internal emigration in the profession". It is manifested by the reluctance on the part of some colleagues, or simply in the refusal to participate in traditional construction industry conventions, mostly dominated by those academics who are involved in the theory of construction. A clear-cut example of this state of things may be our image at the "Krynica conferences" [7-9].

The share of individual fields of specialization in the national academic research conference of the Civil Engineering Committee of the Polish Academy of Sciences, and in the Science Committee of the Polish Association of Construction Industry Engineers and Technicians (PZITB) puts those specialist fields on display. The "Construction Engineering and Management" issues, or Management and Organization issues in the construction industry have their well deserved place in the Civil Engineering Committee and at the Krynica conferences. Nevertheless, a decrease in the number of papers sent to the Conference in recent years, as well as an exceptional dispersion of the subject matter have jeopardized the existence of the session named "Organization and Management in the Construction Industry". Merely 7 to 12 papers have been sent within the last 3 years, quite often from outside of the "traditional" academic environment. According to the Authors, the number of papers sent should at least be trebled.

Perhaps a question whether the set of papers registered for the Krynica conferences is representative of our academic environment is worth considering. The answer is negative. All of us take responsibility for the quantity and the quality. The details of the background within the analyzed field of specialization at the two Krynica conferences (1999 and 2000), as well as a summary of the heritage of this field of specialization, and a comparison with the achievements of other groups of researchers have been presented in paper [9].

Branch conferences have become highly competitive with the Krynica conferences. One of those is the conference of "TOB" single-aspect teams ("Construction Processes"), and BUDIN seminars [1], as well as the Risk Management conferences [2]. Perhaps the formula of the Krynica conferences needs changing, nevertheless the members of the PAN Civil Engineering Committee have stressed the need to integrate the world of science so that exchange of information between fields of special- 
ization may be feasible. In view of this, the Section's survival and continuation of the sessions "Organization and Management in the Construction Industry" in Krynica seems indispensable, because the absent have no say. The proposal to make it obligatory for TOB assistant readers and extramural students of doctoral studies to publish and give papers at the TOB conventions does not seem to be very realistic. The trend for checking the level and research methods, as well as making introductions to the world of researchers should stem from natural needs and from the tradition of honest scientific criticism in our field of specialization.

\section{Research work and dissertations}

Making an inventory of doctoral dissertations and the envisaged post-doctoral dissertations resulted in some interesting data. The review covered a period of 10 years and touched upon a wide range of promotional work, ie on construction technology, mechanization, robotics, economics, management and organization.

As it was easy to foresee, the subject matter of doctoral dissertations varies, ie as far as the formulation of a thesis is concerned and in the approach to the problem. The range has changed significantly, though there are new subjects in management and marketing in the construction industry itself, in contrast to the previous period when the issues discussed had to be limited to the building site only. In spite of this, all still depends on the character and attitude of the Faculty Council. Where the number of independent research staff in our field of specialization is small, they will be under a certain pressure. There are examples, though, of the specific "pressure" helping to write doctoral dissertations at a very sophisticated level which, in turn, often brings about awards or prizes in official construction industry competitions (examples of this may be doctoral dissertations $[10,11])$.

Quite unexpectedly, a "shameful" problem has come up, namely of forecasting doctoral dissertations. It is probably the result of uncertainty as to whether a candidate will continue until the finals, whether or not he or she will continue working at the university. It seems that Scientific Councils differ in their requirements as to what is needed to start writing a doctoral dissertation: the required progress of the work itself seems to be different in different universities and the necessary number and quality of publications also seem to vary.

The following phenomenon has been observed: very often doctoral dissertations are written on the subject of structural engineering or construction materials technology and later, those $\mathrm{PhD}$ degree holders continue their work in the field of construction organization or even in economics. The reason for this is twofold: firstly, living conditions, including salaries (it is often the case that engineers with PhD in construction apply for real estate assessment jobs), and secondly, the didactic needs of faculties and chairs (due to an increased number of students of our specialist fields of study).

It is quite evident that TOB as a specialist field has been upgraded from the level of issues of process organization on the building site to a higher level, namely to organizing and managing the investment process, and has stepped into the world of construction companies. The market structure of the construction industry is governed by a specific model of functional interrelations. Curricula must be adjusted to this new reality, there is a new research field opening up before us. "The Model of Functional Interrelations in the Market Structure of the Construction Industry" is presented in [12]. The following sectors are identified:

- real estate market,

- construction materials and services market, and

- construction investments market.

Doctoral dissertations are being written on those subjects. The point is to convince our colleagues from the specific Faculties (and Scientific Councils) to accept those changes and to include the issues of management and organization into everyday activities of the Construction Faculties. This will certainly not mean laxity for promotional works on the subject. In order to convince those groups of academic teachers, we must be on the lookout for interesting subjects, and research particular phenomena, the solution should be based on a foundation of a range of research work, supported by attractive (new) methods.

An evolution, involving a change in the conditions and range of research and research methods, has taken place in Poland. Three characteristic working hypotheses can be formulated here:

- An extended scope of research as a result of changes in techniques and technology, materials, and production and services market organization, as well as changes in social expectations (political system change): for nearly 40 out of the 50 years taken into consideration, the construction industry (including enterprises) has been functioning in the centralized economy conditions;

- Purely technical problems of building itself are becoming less important: the capability to do construction work is no longer sufficient; what has become important is the issues of cost, time, and quality (in trying to win the market and the client);

- What is clearly noticeable is a change in the trends: from taking interest in the issues of organization to the issues of a more generally conceived management. Organizing and organization have clearly become a subject of management.

These preconditions influence research issues present in the organization of the investment process in the construction industry: the way a construction company operates, organization and management methods as well in the sphere of introducing machinery, robots, and automating processes. The state of research in this field, com- 
parisons made with research in more developed countries, as well as priorities of research problems will be presented in the report [13] being prepared for presentation at the 2002 Krynica Conference, to celebrate the $50^{\text {th }}$ anniversary of the PAN Civil Engineering Committee.

In some academic centres no research seminars are taking place at all. On the one hand, there is a need for discussion, criticism, permanent review of new issues, so as to turn those activities into a tradition. On the other hand, this need is juxtaposed by an enormous teaching load and, consequently, lack of time for research. The influence exerted by a leader (professor), working with young researchers is evident both in the quality of research dissertations and in the number of students of doctoral studies. Shared publications are considered to be a natural gauge of such cooperation (unless achieved by adding one's name to the list of authors!).

Judging from the questionnaires and interviews, it is becoming more and more difficult to find a subject with a good potential. New research techniques and research tools, such as the integrated computer and video camera tool, have come up and observation is carried out not haphazardly but permanently, covering the whole working cycles (including statistical processing). No subjects have been noted during the period of time covered by the questionnaire which would touch upon the use of artificial neuron networks, or genetic algorithms. After the questionnaire work had been concluded, a doctoral dissertation was presented and defended on "The Assessment of the Rate of Technical Deterioration in a Selected Group of Homes, using Artificial Neuron Networks" [14]. Voices have been heard that we should return to the well "tested" methods, namely digital simulation of events.

What is worrying according to the authors is the change in the research profile. The recent "TOB" conference showed that questionnaire-based research had become quite popular. This is particularly clear in researching:

- management risks,

- bidding strategies,

- company strategies,

- quality management,

- and even indirect costs.

This type of research results in "qualitative" data and, which is more, the data are fuzzy. The problem is how to translate them into "quantitative" data, ie into a normative approach. The only successful attempt in this area to-date has been E. Plebankiewicz's research work on bidding strategies [15].

If there is some information about future doctoral dissertations, the availability of information about future post-doctoral dissertations (habilitations) is much worse. In some cases, the subject provided in the summary of titles had to be quoted from personal knowledge of the source. Does it not seem to be an exceptionally "shameful" topic? The post-doctoral degree is supposed to be crowning a certain period of research work, a synthesis of scientific speculation, and ought not to be regarded the way it has been until now. Many academic centres suffer from the shortage of independent research staff. There has been internal re-shuffling within the Faculties, and the numbers of Institutes or Chairs adjusted to fit the number of independent research staff. The most drastic case occurred in Cracow just recently - once the strongest national centre, rich in independent researchers, has faced the fact of having only two such researchers. Consequently, the former Institute of Construction Technology and Organization has been renamed into the Institute of Management in Construction and Transportation. An institute or chair should be strong in a properly qualified staff. We have mentioned a "dissertable leader" above, whereas when an organization's the development is concerned, the following statement seems to be true: a leader who has failed to educate someone to follow in his footsteps must go, a leader who has someone to replace him may go.

In the period covered by the questionnaire, 6 professors were granted their academic titles (Professors), the majority of doctoral dissertations were presented at the Universities of Technology in: Warsaw, Gliwice, Poznan, and Lublin (4 each). At the moment, the highest number of students of doctoral studies are in Cracow and Wrocław (4 each). After the questionnaire was concluded, ie in 2001, three post-doctoral dissertations have gained approval: in the Wrocław University of Technology [16], the Officers' College in Wrocław [17], and in the Lublin University of Technology [18].

Against this background, the following data seems to be at the counterpoint: the highest percentage of professors and Section members occurs in Warsaw, whereas the numbers illustrating future doctoral and post-doctoral dissertations in the capital city seem to be quite pessimistic. Two other centers, Gliwice and Cracow, have reported impressive numbers of future post-doctoral dissertations. The data quoted in the questionnaire suggests that the prospects of the development of the "provincial" centres are very optimistic.

\section{Profile and characteristics of publications}

The interviewed centres gave summaries of their non-serial publications (monographs, academic scripts) and a list of articles. The reported number of articles and published papers are impressive. The titles of periodicals vary: there are a few dozens of them. Nonetheless, merely looking at the titles themselves, it is possible to assess the specific character of a given academic centre.

Unfortunately, a vast majority of the publications are papers formerly included in the materials of various conferences and symposia (including those held abroad). The percentage of such publications is $80-90 \%$, while in some academic centres, it is well over $90 \%$. The percentage is much lower where a centre is more focused 
on technological issues. Two sets of researchers may serve as examples: the Z-1 Department of the Warsaw University of Technology, and the Construction Processes Chair of the Silesian Technical University in Gliwice.

Those figures should be looked upon in a different light: the State Committee for Scientific Research (KBN) warns that it would not (within the score system) take into consideration research papers when assessing individual structural units, and when allocating funds for research work.

The titles of the periodicals themselves prove a great dispersion of research subjects in single-aspect units: from construction engineering, technological and material issues, to legal and ergonomic subjects. Thus, we have seen some "extreme" periodicals emerging, like Inzynieria $i$ Budownictwo and Higiena Pracy.

The respondents have repeatedly lodged a complaint that there is no periodical currently, reflecting the issues in which the Section is involved. According to the authors, there are many such periodicals, and they are not even properly used. For example, only a few authors wrote to Problemy Rozwoju Budownictwa. There are very few articles in Archives of Civil Engineering (AIL). A good and friendly periodical Metody Komputerowe $w$ Inzynierii Lqdowej (with 4 points scored in the KBN!) was closed in 2001 due to the permanent lack of articles! A new periodical, Pion, with "Technology and Organization in the Construction Industry" in the subtitle, was closed in 2002, shortly after it was launched. There are other Polish periodicals, too: from Przeglad Budowlany to other, well read bulletins (for example, those published by Construction Industry Chambers). Not many have used the opportunity of publishing in Statyba (Lithuania) or in Construction Management \& Economics (UK). Another surprise is the lack of our articles in ASCE periodicals, and in the European Construction Management \& Economics (UK).

The majority of articles originating from the academic environment interviewed by the questionnaire have been published in Przeglad Budowlany. An influence of the specificity of a team or an influence of regional needs becomes clear in the summaries from individual centres. In Bydgoszcz, for example, issues resulting from à cooperation with the Scientific Society for Organization and Management are dominant: they are published in Organizacja i Kierownictwo and in Przeglad Organizacji; in Gdańsk: Inzynieria Morska i Geotechnika. In Warsaw, apart from Przeglad Budowlany, there is Forum Budowlane. In Zielona Gora it is the legal and ergonomic issues that come to the forefront, so a number of articles appeared in Higiena Pracy, too.

The teams which publish in quality periodicals of high standing are worth mentioning. One of them is the team led by Prof T. Kasprowicz (WAT - Military University of Technology) who must be mentioned due to the periodicals where they publish (AIL, Biuletyn WAT), and due to their participation in recognized conferences abroad (USA, Australia, Japan). Another notable team is the one led by Prof J. Szwabowski in Gliwice: they are seen thanks to the widest variety of renowned periodicals, which indirectly results from the specificity of the issues researched (technology and construction materials).

Irrespective of any formal didactic collaboration within the framework of international programmes, a less formal collaboration has been going on, expressing itself in some shared publications. It shows in the following academic centres: Gliwice [19], Lublin [20, 21], Częstochowa [22], and Poznan (in the latter case, one of the results is a shared monographic work entitled "Expert Systems in Construction Industry", published in Vilnius, 1995) [23, 24].

The majority of articles published in Przeglad Budowlany were written by Prof K. Cieszyński. Statyba has proved to be the most popular foreign periodical, with the Journal of Construction Management and Economics (UK) coming second.

In some cases, the specific character of particular academic centres can be defined from their list of publications.

Thus, traditionally, Cracow deals with mathematical methods and management while technology dominates in Gliwice. Warsaw (The Warsaw University of Technology) stands out due to their interest in the issues of the construction industry market, and macro-organization in construction engineering (Prof K. Cieszyński), as well as pre-fab technologies, quality, ISO norms (Prof G. Chrabczyński et al.). Wrocław presents a merger of organization and construction (thus the most numerous patent applications). In Poznań, it is decision support and artificial intelligence, in Gdańsk it is hydrotechnical constructions, in Bydgoszcz it is risk management, construction law in Zielona Góra, repair work technologies in Kielce, company economics to mechanization in Częstochowa, and logistics and process modelling in Lublin.

The standing of a given academic environment is largely supported by books, monographs, and academic scripts. The number of such publications in the last few years is quite impressive. They can be divided according to the following subjects:

- investment processes organization [25-28], and construction industry contracts $[29,30]$,

- managing a company [31-34],

- marketing in the construction industry $[35,36]$, business plan [37], management accounting [38],

- risk management $[2,34,39,40]$,

- organization and modelling of construction processes $[16,17,41-46]$,

- logistics [18],

- ergonomics [47],

- production engineering in the construction industry $[48,49]$,

- expert systems $[17,23]$, 
- methodology $[17,41,45,50,51]$,

- mechanization in construction work $[22,52,53]$,

- technological issues [53-59].

In countries such as Poland, formal post-doctoral dissertation (habilitation) presentations are a living proof of staff development. Seven such dissertations were reported in the last few years $[16-18,39,43,44,52]$.

\section{Other elements, characterizing the environment of researchers}

The academic centres covered by the questionnaire have been characterized. Complete numerical data were provided in the paper [60] in Polish, entitled "Promotional Works and Publications, as Shown in the Questionnaire of the Construction Management Section of the Civil Engineering Committee of the Polish Academy of Science"

Warsaw has a proven the greatest number of authors, which justifies the numerous representation of this environment in the Section. It is also extremely diversified. In the Warsaw University of Technology, Z-1 Department (Department of Technology and Organization of Building Materials Production) has clearly dominated the University's two other Departments both in respect of its staff and the outcome of its international cooperation, visits, contacts, and publications in renowned journals, including those in other countries. Evidently, Z-1 has a different profile, dealing with building materials which may account for the fact that its accomplishments are so explicit. By analogy to the success of part of the Gliwice team, where there is more technology, there the measurable outcome of work is more substantial. In these circles, Prof W. Wemer is a particularly recognized researcher due to his publications and promotional works cf $[25,26]$.

The Section members are or have been performing responsible duties in their parent universities: eg rector or vice-rectors, deans or vice-deans as well as directors of institute, including deputy directors for research. Furthermore, two former deputies to the Parliament (Sejm), the lower chamber of our parliament (Prof T. Biliński and Dr A. Chrzanowski - the Chairman and Member of the Sejm Commission for Physical Planning, Construction and Housing Policy) come from our circles, namely the Institute of Building Engineering (including the Department of Construction Engineering and Management) in Zielona Góra.

The Section members and other researchers are highly active professionally, for instance, they sit on Supervisory Boards or Boards of Management in various companies (one person is working for the National Investment Fund), in professional self-governments, assorted associations of researchers and professionals. Some of them are court-appointed experts, public procurement arbitrators, cost assessment experts, or certified property valuers. Worth mentioning is a certain change in the scope of these functions or lines of specialization: the former "PZITB experts", ie those appointed by the Polish Association of Construction Industry Engineers and Technicians, have been replaced by experts in quality management, ISO certification or developer certification, and by certified property valuers. Our Property Management Act of 21 August 1997 introduced three professional activities: certified property valuer, real estate agent, and property manager (vide Section V, Chapters 1,2 and 3). Moreover, some of our colleagues in several centres sit on editorial boards of Polish journals of technology and of various scientific journals abroad.

The academic centre in Wroclaw has the highest number of own businesses (12) among all. Some centres are not involved in this kind of activity. Warsaw is an environment with the highest opinion-forming potential, resulting from its cooperation with various ministries or central agencies, participation in assorted competition boards or certification committees

All the centres that have responded to the questionnaire are running courses and seminars for industry on a commercial basis. These are usually post-graduate courses, most of them in the subject of property valuation. Consequently, the staff are heavily overloaded with didactic activities.

Organization of conferences and symposia of assorted profiles is a characteristic quality of this environment. Worth mentioning are meetings of single-aspect teams - a kind of conferences organized alternately by various centres once a year. These conferences are superbly prepared. The procedure to accept and deliver the papers was changed 3 years ago [5] and now each paper is reviewed, then delivered and discussed [3-6]

\section{International cooperation}

Many contrasts are seen in the area of international cooperation. A few centres, eg the Warsaw Technical University, are regularly involved in such cooperation, organizing a number of symposia. Poznań is engaged in a trilateral cooperation between Lithuania, Germany and Poland which involves scientific conferences, consulting for promotional works, reviewing, and joint research works. The most spectacular effect of cooperation in the framework of programs such as TEMPUS, SOCRATES, and COPERNICUS was achieved by the Chair of Building Processes of the Silesia Technical University (Gliwice). Some centres are entirely inactive in this respect. As few as four centres have prepared publications jointly with their foreign colleagues. One of us, Prof O. Kapliński, is member of the Ukrainian Academy of Construction and a doctor honoris causa of the Vilnius Gediminas Technical University. As regards visits to foreign academic centres, the situation is not as good: most of the visits lead to Slovakia and its four universities.

The spectacular transborder cooperation between the three universities, in Lithuania, Poland and Germany, 
started in 1986. The outcome of it to date has been a hundred publications. A complete list of such publications was made by E. Zavadskas and A. Kaklauskas [61] on the occasion of last conference, held in 2001 in Vilnius. Prof E. Zavadskas reviewed a doctoral dissertation in Poznan. [10]. Professors from Poland participate in scientific commissions, evaluating doctoral dissertations and post-doctoral dissertations in Lithuania. For instance, two post-doctoral dissertations on construction management [62-64] were evaluated with Prof O. Kaplinski's participation. It is emphasised that the cooperation is smooth and free of xenophobia, running in the spirit of integral humanism. The two leaders, from Poznań and from Vilnius, have been honoured with the Integral Humanism Medal, furthermore, Prof E. Zavadskas has been conferred the title of doctor honoris causa of the Poznan University of Technology in 2002.

This cooperation covers the following research issues:

- location problems,

- problems of balancing construction processes under stochastic and unspecified conditions,

- reliability of production systems,

- property valuation methods,

- decision support systems,

- e-commerce problems,

- applications of game theory and fuzzy sets,

- various aspects of managing a construction company,

- renovation of architectural monuments,

- but most of all, the issues of multicriterion optimization, based mainly on a wide spectrum of works by E. Zavadskas; ie from [65] to [66].

The development of individual academic centres depends on specific conditions, affecting education and research. The problem was pointed out by E. Zavadskas and A. Valiulis in their book [67]. Similar conditions and the resulting mechanisms are observed not in Lithuania alone but in Poland as well. Therefore, this cooperation found understanding on both parts and is very well motivated.

\section{Final remarks}

1. The results of this questionnaire are of a high cognitive value: they form a basis for exchange of information about the undertakings of the specific academic centres. Indirectly, the results of the questionnaire are supposed to further facilitate our identification of our researchers' environment and the Section itself.

2. The most positive fact resulting from this analysis is that the issues of construction organization and management have been experiencing a specific renaissance, both in research and applications.

3. An assumption can be made that research in Poland, as illustrated in the above analysis, has been following the changes resulting from a market economy in the making.

4. All the same, we find it alarming that, in developed countries, the same issues are much better understood by engineering and academic circles.

\section{References}

1. Proc. of IV Seminar: Management in investment process in construction - BUDIN 2001. Dolnośląskie Wydawnictwo Edukacyjne. Wrockaw, 2001 (in Polish)

2. Risk management in enterprise, Ed.: J. Bizon-Górecka. BGJ-Consulting, Bydgoszcz -. Ciechocinek, 2000 (in Polish).

3. Proc. of Conference: Technology and organization in construction industry in beginning of XXI century. Przedsiębiorstwo Budownictwa Przemysłowego „PUŁAWY“ S.A., Pulawy, 2001 (in Polish).

4. Proc. of Conference: Technological, organizational and economical aspects of construction industry development. Olsztyn -- Lańsk. Uniwersytet Warmińsko - Mazurski w Olsztynie, Olsztyn, 2002 (in Polish).

5. Proc. of Conferenc: Construction processes 1999. Szczecin -- Miźdzyzdroje 1999. Vol 2. Wydawnictwo Uczelniane Politechniki Szczecińskiej, Szczecin, 1999 (in Polish).

6. Proc. of Conference Construction processes 2000: Realization of processes and buildings. Gliwice - Kokotek 2000. Wydawnictwo Politechniki Śląskiej, Gliwice, 2000 (in Polish),

7. Proc. of XLVI Conference KILiW PAN and KN PZITB. Vol 3. Wrocław - Krynica. Politechnika Wrocławska, 2000 (in Polish).

8. Proc. of XLVII Conference KILiW PAN and KN PZITB Vol 3. Opole - Krynica. Politechnika Opolska, 2001 (in Polish).

9. Kapliński, O. Construction management problems at Civil Engineering Conferences in Krynica. In; Proc. Conference: Construction processes 2000, Gliwice - Kokotek, 2000, s. 81-86 (in Polish).

10. Thiel, T. Methodological aspects of multi-criterion decision aid in civil and construction engineering. $\mathrm{PhD}$ thesis, Poznań University of Technology, Poznań, 1997 (in Polish).

11. Hajdasz, M. Rule-based knowledge in the system supporting the design for building grain silos erected by the slip method. PhD thesis, Poznan University of Technology, Poznan, 1998 (in Polish).

12. Projekt Leonardo da Vinci: The model of functional interrelations in the market structure of the construction industry. In: Knowledge structure for syllabus ,Management and production engineering in construction industry". Instytut Technologii i Organizacji Produkcji Budowlanej, Politechnika Warszawska, 1999-2000 (in Polish).

13. Kapliński, O.; Werner, A.; Kosecki, A.; Biernacki, J.; Kuczmarski, Fr. Management, organization and mechanization in construction industry. In: Proc. of XLVIII Conference KILiW PAN and KN PZITB: Opole - Krynica. Politechnika Opolska, 2002 (in print, in Polish). 
14. Urbański, P. The assessment of the rate of technical deterioration in a selected group of homes, using artificial neuron networks. PhD thesis, Uniwersytet Zielonogórski, Zielona Góra, 2001 (in Polish).

15. Plebankiewicz, E. Model of bidding strategies for contractor with fuzzy sets application. PhD thesis, Politechnika Krakowska, Kraków, 2001 (in Polish).

16. Hejducki, Z. Time couplings incorporated in organizational methods of complex construction processes. Oficyna Wydawnicza Politechniki Wrocławskiej. Wrocław, 2000.

17. Szelka, J. Object-oriented notation of knowledge in expert systems for military bridges erection. WAT, Warszawa, 1999 (in Polish).

18. Sobotka, A. Sensitiveness of logistic decisions in building enterprises. Wydawnictwo Politechniki Lubelskiej, Lublin, 2000 (in Polish).

19. Froug, F.; Szwabowski, J.; Wild, S. Influence of superplasticisers on the workability of concrete. Journal of Materials in Civil Engineering. ASCE, Vol 11, No 2, May 1999, p 151-157.

20. Sobotka, A.; Wyatt, D. P. Sustainable development in the practice of building resources renovation. Facilities, Vol 16, No 11, 1998, p 319-325.

21. Sobotka, A.; Mach, B.; Wyatt, D. P. Problems of sustainable renovation of constructions from largesized concrete elements. In: Proc. of conference „Ecology in engineering of construction processes", Kazimierz Dolny, 1998.

22. Sizikov, S.; Jertiuhow, S.; Rajczyk, J. Organization complex mechanization of construction processes. PUAiB, St. Petersburg, 2000 (in Russian).

23. Zavadskas, E.; Kapliński, O.; Kaklauskas, A.; Brzeziński, J. Expert systems in construction industry: trends, potentials \& applications. Vilnius: Technika, 1996.

24. Kapliński, O.; Zavadskas, E. Expert systems for construction processes. Civil Engineering (Statyba), No 4 (12), 1997, p 49-61.

25. Werner, W. A. Management in investment process. Oficyna Wydawnicza Politechniki Warszawskiej. Warszawa, 1999 (in Polish).

26. Werner, W. A. Investment processes for architects. Oficyna Wydawnicza Politechniki Warszawskiej. Warszawa, 2000 (in Polish).

27. Żywica, R.; Meszek, W.; Żywica A. Investment processes organization. Wydawnictwo Politechniki Poznańskiej. Poznań, 2002 (in Polish).

28. Biliński, T.; Czachorowski, J. Organization of investment and building processes. Izba Projektowania Budowlanego, Warszawa, 2001 (in Polish).

29. Kietliński, W. et al. Risk in construction industry contracts. Verlag Dashöfer, 1999 (in German).

30. Czachorowski, J. et al. Standardized of requirements for order and realization of construction works. DIN 196 ! Part B and DIN 18299 Part C, VOB, Beuth Verlag, Berlin, Wien, Zurich, 1999 (in Polish).

31. Pabian, A. Enterprise success on market. Wydawnictwo Politechniki Częstochowskiej, 1998 (in Polish).

32. Żywica, R. Managing of building firms. Konin-Poznań. Wyd. II and III, 1997 and 1998 (in Polish).
33. Glowacz, Ł. Economical analysis. Wydawnictwo Politechniki Krakowskiej, 1999 (in Polish).

34. Bizon-Górecka, J. Reliability engineering and risk in enterprise management. Oficyna Wydawnicza OPO, Bydgoszcz, 2000 (in Polish).

35. Pabian, A. Marketing in construction industry. $\mathrm{CIOB}$ Warszawa, 1999 (in Polish).

36. Linczowski, C. Organization, management and elements of marketing. Wydawnictwo Politechniki Świętokrzyskiej, Kielce, 1999 (in Polish).

37. Pabian, A. Business plan. CIOB Warszawa, 2000 (in Polish).

38. Kozłowski, J;; Piechocki, M.; Sowiński, E. Management accounting. Wydawnictwo Wyższej Szkoły Morskiej w Gdyni, 1999 (in Polish).

39. Bizon-Górecka, J. Method of risk management in construction production. Wydawnictwo Akademii TechnicznoRolniczej, Bydgoszcz, 1998 (in Polish).

40. Bizon-Górecka, $\mathbf{J}$. Monitoring of risk factors in enterprise. OPO-TNOiK, Bydgoszcz, 1998 (in Polish).

41. Kapliński, O. Modelling of construction processes: A managerial approach. KILiW PAN, IPPT, Studia z zakresu inżynierii No 43, Warszawa, 1997.

42. Mrozowicz, J. Methods of construction processes organization with time couplings. Dolnośląskie Wydawnictwo Edukacyjne. Wrocław, 1997 (in Polish).

43. Więckowski, A. Environmental science and economical model of realization of processes in building cycle. Wydawnictwo Politechniki Krakowskiej, 1999 (in Polish).

44. Przybylski, J. Formalization of technological and organizational processes in construction industry - application complex models. Wydawnictwo Politechniki Zielonogórskiej, 1999 (in Polish).

45. Jaworski, K. M. Methodology of building realization designs. PWN, Warszawa, 1999 (in Polish).

46. Marcikowski, R. Methods of time scheduling for building projects. WAT, Warszawa, 1995 (in Polish).

47. Taczanowska, T.; Jaśkowski, P. Ergonomics in construction industry. Wydawnictwo Politechniki Lubelskiej, Lublin, 1998 (in Polish).

48. Martinek, W. Osiecka, E. Ground of building production engineering. Oficyna Wydawnicza Politechniki Warszawskiej. Warszawa, 1999 (in Polish).

49. Maciąg-Sternik, H.; Rowiński, L. Technology and organization of engineering processes in town building. Part IV, Wydawnictwo Politechniki Śląskiej, Gliwice, 1998 (in Polish).

50. Kapliński, O., editor. Applied computer science in construction production. Wydawnictwo Politechniki Poznańskiej, Poznań, 1996 (in Polish).

51. Szwabowski, J.; Deszcz, J. Multicriterial methods of comparative analysis. Wydawnictwo Politechniki Śląskiej, Gliwice, 2001 (in Polish).

52. Rajczyk, J. Ground of scientific selection of machines rational parameters. Wydawnictwo Politechniki Częstochowskiej, 1999 (in Polish).

53. Rajczyk, J.; Rajczyk, M. Technology of stone works. Wydawnictwo Politechniki Częstochowskiej, 1997 (in Polish). 
54. Martinek, W.; Michnowski, Z. Roofwork and building tinsmithing. Wydawnictwa Szkolne i Pedagogiczne, 1999 (in Polish).

55. Martinek, W.; Szymański, E. Brickwork and plasterwork. Wydawnictwa Szkolne i Pedagogiczne, 1999 (in Polish).

56. Osiecka, E.; Szymański, E.; Nicewicz, S. Utilization of wastes from energetic industry for building materials production. Oficyna Wydawnicza Politechniki Warszawskiej, 1998 (in Polish).

57. Linczowski, C. Repairs and buildings modernizations. Wydawnictwo Politechniki Świętokrzyskiej, Kielce, 1997 (in Polish).

58. Tokarski, Z. Analysis of modern technologies for roads construction in Holland. Wydawnictwo Akademii Techniczno-Rolniczej, Bydgoszcz, 1999 (in Polish).

59. Szwabowski, J. Rheology of cement binder compositions. Wydawnictwo Politechniki Śląskiej, Gliwice, 1999 (in Polish).

60. Kapliński, O. Doctor's theses and publication's achievements in inquiry of construction management section. In: Proc. of Conference: Technology and organization in construction industry in beginning of XXI century. Przedsiębiorstwo Budownictwa Przemysłowego „PUŁAWY“ S. A., Puławy, 2001, p. $67-88$ (in Polish).
61. Zavadskas, E. K.; Kaklauskas, A. History and trends of development of colloquy. Civil Engineering (Statyba), Vol VII, No 4, 2001, p. 265-275.

62. Ginevičius, R. Situation analysis of organisational management structures at building enterprises and their formation (Statybos imonių organizaciniu valdymo struktūru situaciné analizè ir formavimas). Vilnius: Technika, 1996 (in Lithuanian).

63. Ginevičius, R. Die Situationsanalyse and Gestaltung der organisatorischen Leitungsstrukturen von Bauunternehmen. Technische Gediminas Unversität in Vilnius. Vilnius: Technika, 1997 (in German).

64. Kaklauskas, A. Multiple criteria decision support of building life cycle. Research report presented for Habilitation. Vilnius: Technika, 1999.

65. Zavadskas, E. K. Sistemotechnical evaluation of technological decisions in constructional manufacture (Системотехническая оценка технологических решений строительного производства). Leningrad: Strojizdat, 1991 (in Russian).

66. Zavadskas, E. K. Mehrkriterielle Entscheidungen im Bauwesen. Vilnius: Technika, 2000 (in German).

67. Zavadskas, E. K.; Valiulis, A. V. A time of challenge and university's growth. Vilnius: Technika, 2002. 